\title{
Quality Function Deployment (QFD): A Six Sigma Tool for Performance Monitoring of Ready Mixed Concrete
}

\author{
Debasis Sarkar $^{1}$, Riki Panchal ${ }^{2}$ \\ Associate Professor and Head, Dept. of Civil Engineering, School of Technology, Pandit Deendayal Petroleum \\ University, Gandhinagar, Gujarat, India ${ }^{1}$
}

Former M. Tech Student, Infrastructure Engineering \& Management, Pandit Deendayal Petroleum University,

Gandhinagar, Gujarat, India ${ }^{2}$

\begin{abstract}
Six sigma tools appear to be quite effective for monitoring the quality of Ready Mixed Concrete (RMC). Quality function deployment (QFD) is such a Six sigma tool which can prove to be very effective for monitoring the performance of RMC. Customer satisfaction is a very important component for RMC plants to maintain its quality and reputation. Thus Voice of Customer $(\mathrm{VoC})$ which is a part of QFD deserves to have a special focus in formulation of QFD model. QFD process can be integrated with available statistical process control tools like CUSUM with v-mask, RACUSUM and MVCUSUM to develop a more robust methodology for quality and performance monitoring of RMC. This paper is an attempt to develop a QFD model which is customised to monitor the quality of RMC by giving priority towards customer requirements and satisfaction. Case studies of two RMC plants in Ahmedabad region of Gujarat, India have been considered for this research work. It is observed that for all the RMC plants there is an urgent need to establish a "customer care unit" which can address the issues of the customers and communicate the problems to the respective departments for quick and early action.
\end{abstract}

Keywords: Quality Function Deployment (QFD), Six sigma, Performance monitoring, Ready Mixed Concrete (RMC).

\section{INTRODUCTION}

Quality Function Deployment (QFD) supports design teams to develop products on a structured way that relates customer demand via engineering specifications to parts specifications and to production process variables and thus to production operations planning. (Govers, 1996) The emphasis on "voice of the customer" is the key to QFD (Kamara et al. 1999). QFD in the construction industry has gained a whole new meaning and importance with the increasing trend to adopt project procurement using the design/build (D/B) method (Pheng. 2001). For the need to understand the critical design issues prior to production quality control process charts were widely used to ensure that the design criteria were met during manufacturing, but there was no formal system to translate the customer's needs into the initial design and subsequent process control points. Thus, an opportunity was created for QFD to come to fruition as a method to check the design itself for adequacy in meeting customer requirements and to translate those requirements to production. (Jaiswal. 2012)

The QFD method includes building one or more matrices known as 'quality tables'. The matrix is named as the "house of quality" (HoQ). It exhibits the customer's needs or voice of customer ( $\mathrm{VoC})$ on the left hand side, and the technical response to meeting those needs along the top. Ready mixed concrete (RMC) is a product which also should satisfy the requirements of the customer or consumer. The quality monitoring of RMC should have a major focus towards customer satisfaction. Thus, this paper is an attempt to explore the application of QFD and particularly HoQ in monitoring the quality of RMC produced by commercial batching plants with special focus on customer satisfaction.

\section{LITERATURE REVIEW}

QFD is a customer-oriented approach for product or process development. It guides product or process managers and design teams through the conceptualization, creation and realization process of new products or processes. QFD supports design teams to develop products on a structured way that relates market demand via engineering specifications to production process variables and thus to production and operations planning. An organized QFD approach follows all the rules for project management, which means project definition, team selection and is not restricted to a single action within just one department. Teams should be cross-functional, expertise oriented and consisting of six to eight members of comparable peer levels. (Govers, 1996). According to Bouchereau and Rowlands (2000), Heizer and Render (2006), QFD is an useful tool for providing a systematic approach to translating customer desires into product or process attributes. The house of quality matrix provides a 
Vol. 4, Issue 2, February 2017

framework with definite guidelines that help take nonmeasurable or abstract customer wants and link them with practical actionable steps that will create a product or process that has a competitive advantage over competitors. The basic model of HOQ was demonstrated by Heizer and Render (2006), Bouchereau and Rowlands (2000).

According to Cristiano et al., 2010 successful companies in today's dynamic global economy are those that are able to efficiently design, develop, and manufacture products that will be preferred by customers over those offered by competitors. The emphasis on "voice of the customer" is the key to QFD (Kamara et al., 1999). QFD in the construction industry has gained a whole new meaning and importance with the increasing trend to adopt project procurement using the design/build (D/B) method (Pheng, 2001). For the need to understand the critical design issues prior to production quality control process charts were widely used to ensure that the design criteria were met during manufacturing, but there was no formal system to translate the customer's needs into the initial design and subsequent process control points. Thus, an opportunity was created for QFD to come to fruition as a method to check the design itself for adequacy in meeting customer requirements and to translate those requirements to production. (Jaiswal, 2012)

During the past decade, the construction industry in India witnessed remarkable growth, in which the RMC industry can claim to be a proud partner. But producing of superior quality concrete in economic prices is a major issue. The methods and processes for quality control and assurance of RMC for Indian commercial batching plants is not adequate to match global standards. A series of statistical quality control (SQC) and statistical process control (SPC) methods for quality monitoring of RMC have been suggested by Sarkar and Bhattacharjee (2003). The SPC method applied by them for quality monitoring of RMC was CUSUM technique with $\mathrm{v}$ - mask. The producers' risks and the consumers' risk associated with RMC manufacturing need also to be kept within specified limits for producing superior quality concrete. Thus, Sarkar and Thaker (2007) tried to quantify the producers' risk and consumers' risk by application of operating characteristic (OC) curves. Further, Sarkar and Dutta (2010) made an attempt to incorporate the risks involved during the production process along with the conventional CUSUM and developed a risk adjusted CUSUM model which they termed as RACUSUM model for quality monitoring of RMC. They believed that the RACUSUM model was more effective than the conventional CUSUM model. Sarkar (2009) applied another SPC chart termed as exponentially weighted moving average (EWMA) for quality monitoring of RMC and also tried to track the relative advantages and disadvantages of both the techniques. It was observed that CUSUM technique with $\mathrm{V}$ - mask was more sensitive and producing better results than EWMA technique. There was also a need to develop an economic design model for Indian RMC industry which Sarkar and Dutta (2009) had made an attempt and the model developed by them was gradually accepted by the industry.

Most of the models developed were dealing primarily with one quality parameter or characteristic which is strength of the grade of concrete monitored. But higher degree of quality monitoring can be carried out if multiple quality characteristics can be monitored simultaneously. Thereby, Sarkar and Bhattacharjee (2014) made an attempt to develop a multivariate CUSUM methodology (MVCUSUM) where the other parameters like slump, density and temperature of fresh concrete which affects the quality of RMC can be monitored. Reviewing the available literature, it is observed that though maintaining superior quality of RMC is definitely a serious concern for construction industry, but also there is a major requirement to address the issues of the consumers or customers. Thus this paper is an attempt to explore the potentiality of application of QFD and particularly HOQ which primarily focuses on customer satisfaction, for performance monitoring of RMC.

\section{CASE STUDY AND ANALYSIS}

Primary Data has been collected from two commercial RMC plants in Ahmedabad, region of Gujarat, India. The various information collected from plants includes plant name, location, type of plant, capacity of plant, arrangement of components, batching capacity, silo capacity, storage of material, quality control tests, etc. The RMC plants considered for this study and from where the data has been collected include Ultra tech (Case 1) and Lafarge (Case 2).

Table 1: Details of RMC Plants of Ahmedabad Region

\begin{tabular}{|l|l|l|l|}
\hline Sr No. & Description & Case 1 & Case 2 \\
\hline 1 & Plant location & Naroda GIDC, Ahmedabad & Kankaria Stadium site, Ahmedabad \\
\hline 2 & Type of plant & Commercial & In-house \\
\hline 3 & Working of plant & Automatic & Automatic \\
\hline 4 & Capacity of plant & 60 cum/hr & 60 cum/hr \\
\hline 5 & $\begin{array}{l}\text { Material storage } \\
\text { and handling }\end{array}$ & $\begin{array}{l}\text { Aggregates - bins Cement - silos } \\
\text { Admixtures - barrels }\end{array}$ & $\begin{array}{l}\text { Aggregates }(20 \mathrm{~mm} / 10 \mathrm{~mm} / \mathrm{sand}) \text { stored } \\
\text { at site and loaded by dragline/loader }\end{array}$ \\
\hline 6 & Batching capacity & $\begin{array}{l}1 \text { cum per batch. One batch - one } \\
\text { minute }\end{array}$ & 1 cum per batch. One batch - one minute \\
\hline
\end{tabular}


Vol. 4, Issue 2, February 2017

A detailed questionnaire was also prepared to comply the Case 1and 2) as presented in Table 2, "plant and requirements for formulation of the QFD- HoQ model. equipment availability and ensuring that the plant is in The questionnaire consisted of questions that investigate proper functional mode" is the most important parameter the quality maintained before, during and after the (relative weightage $15.8 \%$ ) that need to be taken care by production process. The questionnaire was circulated to 75 the RMC authorities. The next important parameter professionals (plant managers, mix design engineers, plant appears to be "resource management"(relative weightage engineers, quality control and assurance engineers, safety $14.9 \%$ ) followed by "control on quality of incoming engineers and plant supervisors) associated with RMC materials", "laboratory set-up", "application of control industry. The respondents were requested to give the charts", "process control-concrete mix design", "material importance / weightage for the various parameters related testing", "production and delivery of RMC", "presence of to the customer requirements, performance measures, key personnel" and "safety on site". Finally, for process features, technologies, part specification and control phase (Table 3), the QFD-HoQ rating highlights manufacturing process. About 45 respondents responded that "target workability at plant" is most important factor to this study. The primary parameters for formulation of (relative weightage 20.7\%), which the RMC authorities the QFD-HoQ model in product planning phase include need to take care of, followed by "smooth operation of cement type and grade, mineral additive requirement batching plant". The rankings of the parameters obtained (pulverized flyash, slag, silica fumes etc.), quality of in QFD-HoQ matrix in the four phases would enable the concrete, quantity of concrete, delivery on time, cost RMC plant authorities to focus on the most crucial effectiveness, continuous concrete supply, supply at parameters for monitoring the quality of RMC. Thus, remote places, demands of various grades simultaneously according to the primary objectives of QFD-HoQ, and design life. Similarly the other parameters for product customer requirements are transferred to the design phase and process control phase with responses as manufacturing process which helps in building and obtained for Case 1 and Case 2 are presented in tables 2 delivering a quality product or service by focusing towards and 3 respectively. The respondents have given weightage customer satisfaction.

to the vertical parameters from 5 to 1 in the decreasing order of their importance. After that, the relationship matrix need to be filled by giving the rating like "strong relationship" (9), "moderate relationship" (3) and "weak relationship" (1). Table 2 represents the QFD-HoQ parameters for Product Planning Phase. Table 3 represents the QFD-HoQ parameters for Process Control Phase.

Thus the overall and relative weightages are computed by the excel based software "smart draw" which is a software package designed for HoQ computations. It has been observed that for product planning, phase (mean values of methodology.

Table 2: QFD-HoQ Parameters for Product Planning, Phase (Mean Values for Case 1 and 2)

\begin{tabular}{|c|c|c|c|c|c|c|c|c|c|c|c|c|c|}
\hline $\begin{array}{l}3 \\
0 \\
\alpha\end{array}$ & 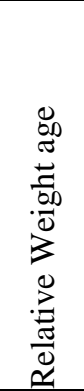 & 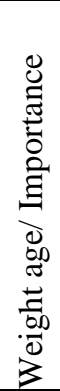 & & 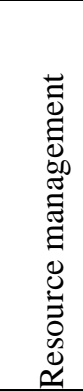 & 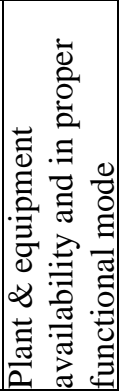 & 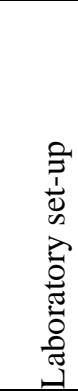 & 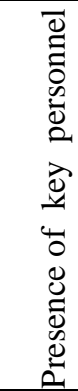 & 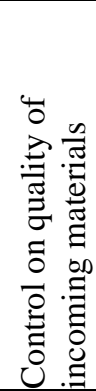 & 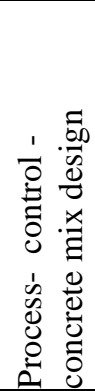 & 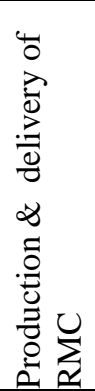 & 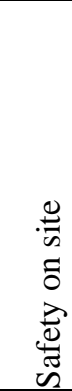 & 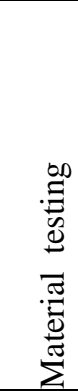 & 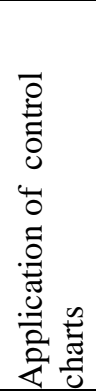 \\
\hline 1 & 11.6 & 5 & $\begin{array}{l}\text { Cement type } \\
\text { and grade }\end{array}$ & 3 & 3 & 9 & 1 & 9 & 3 & 1 & 1 & 3 & 9 \\
\hline 2 & 9.3 & 4 & $\begin{array}{l}\text { Mineral addit } \\
\text { ive requirement } \\
\text { (pulverised fly } \\
\text { ash, slag, silica } \\
\text { fume) }\end{array}$ & 3 & 3 & 3 & 1 & 9 & 3 & 1 & 1 & 3 & 9 \\
\hline 3 & 11.6 & 5 & $\begin{array}{l}\text { Quality of } \\
\text { concrete }\end{array}$ & 9 & 9 & 9 & 1 & 9 & 9 & 1 & 1 & 9 & 9 \\
\hline 4 & 9.3 & 4 & $\begin{array}{l}\text { Quantity of } \\
\text { concrete }\end{array}$ & 9 & 9 & 1 & 1 & 1 & 3 & 3 & 1 & 1 & 3 \\
\hline
\end{tabular}


International Advanced Research Journal in Science, Engineering and Technology

ISO 3297:2007 Certified

Vol. 4, Issue 2, February 2017

\begin{tabular}{|l|l|l|l|l|l|l|l|l|l|l|l|l|l|}
\hline 5 & 11.6 & 5 & $\begin{array}{l}\text { Delivery on } \\
\text { time }\end{array}$ & 9 & 9 & 1 & 3 & 1 & 1 & 3 & 1 & 1 & 1 \\
\hline 6 & 11.6 & 5 & $\begin{array}{l}\text { Cost } \\
\text { effectiveness }\end{array}$ & 3 & 3 & 3 & 1 & 3 & 9 & 1 & 1 & 3 & 3 \\
\hline 7 & 9.3 & 4 & $\begin{array}{l}\text { Continuous } \\
\text { concrete supply }\end{array}$ & 9 & 9 & 1 & 3 & 1 & 1 & 3 & 1 & 3 & 1 \\
\hline 8 & 9.3 & 4 & $\begin{array}{l}\text { Supply at } \\
\text { remote places }\end{array}$ & 1 & 9 & 1 & 3 & 1 & 1 & 9 & 3 & 1 & 1 \\
\hline 9 & 7 & 3 & $\begin{array}{l}\text { Demand of } \\
\text { various grades } \\
\text { simultaneously }\end{array}$ & 9 & 3 & 9 & 3 & 3 & 1 & 3 & 1 & 3 & 3 \\
\hline 10 & 9.3 & 4 & Design life & 1 & 1 & 9 & 1 & 9 & 3 & 1 & 1 & 3 & 3 \\
\hline & & & $\begin{array}{l}\text { Weightage/ } \\
\text { Importance }\end{array}$ & 555.8 & 588.4 & 458.1 & 174.4 & 472.1 & 365.1 & 248.8 & 118.6 & 309.3 & 434.9 \\
\hline & & $\begin{array}{l}\text { Relative } \\
\text { weightage }\end{array}$ & 14.9 & 15.8 & 12.3 & 4.7 & 12.7 & 9.8 & 6.7 & 3.2 & 8.3 & 11.6 \\
\hline & & & Rank & 2 & 1 & 4 & 9 & 3 & 6 & 8 & 10 & 7 & 5 \\
\hline
\end{tabular}

Table 3: QFD-HoQ Parameters for Process Control Phase (Mean Values for Case 1 and 2)

\begin{tabular}{|c|c|c|c|c|c|c|c|c|c|c|c|c|c|c|}
\hline $\begin{array}{l}3 \\
0 \\
2\end{array}$ & 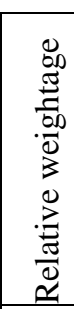 & 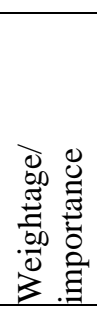 & & 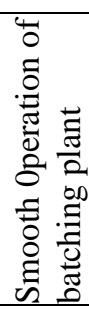 & 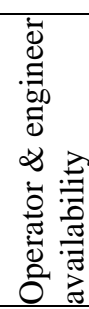 & 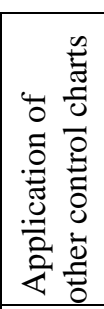 & 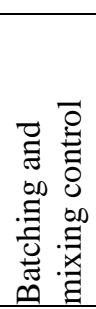 & 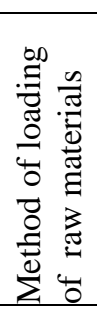 & 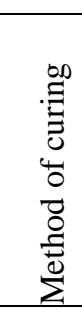 & 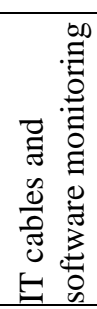 & 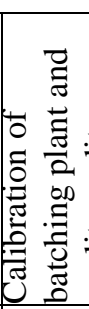 & 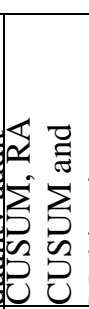 & 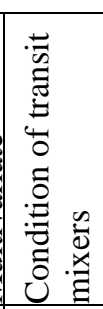 & 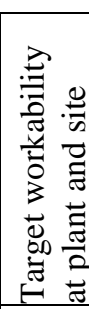 \\
\hline 1 & 5.9 & $\begin{array}{l}109 . \\
4\end{array}$ & $\begin{array}{l}\text { Machine } \\
\text { specifications }\end{array}$ & 9 & 9 & 3 & 9 & 9 & 1 & 9 & 9 & 3 & 3 & 9 \\
\hline 2 & 8.7 & $\begin{array}{l}161 . \\
0\end{array}$ & $\begin{array}{l}\text { Material } \\
\text { handling }\end{array}$ & 3 & 3 & 3 & 3 & 3 & 1 & 1 & 9 & 3 & 3 & 9 \\
\hline 3 & $\begin{array}{l}15 . \\
7\end{array}$ & $\begin{array}{l}289 . \\
9\end{array}$ & $\begin{array}{l}\text { Material } \\
\text { source and } \\
\text { availability }\end{array}$ & 3 & 3 & 3 & 3 & 1 & 1 & 1 & 3 & 3 & 3 & 9 \\
\hline 4 & 5.4 & $\begin{array}{l}100 . \\
0\end{array}$ & $\begin{array}{l}\text { Water tank, } \\
\text { meter and } \\
\text { pumping } \\
\text { system }\end{array}$ & 9 & 3 & 3 & 3 & 3 & 9 & 1 & 3 & 3 & 3 & 9 \\
\hline 5 & 9.5 & $\begin{array}{l}174 . \\
2\end{array}$ & $\begin{array}{l}\text { Monitoring } \\
\text { quality of } \\
\text { ingredients }\end{array}$ & 3 & 3 & 3 & 9 & 1 & 1 & 1 & 3 & 3 & 3 & 9 \\
\hline 6 & 5.9 & $\begin{array}{l}107 . \\
8 \\
\end{array}$ & $\begin{array}{l}\text { Mixer blades } \\
\text { wear }\end{array}$ & 9 & 1 & 3 & 9 & 3 & 1 & 1 & 3 & 3 & 1 & 9 \\
\hline 7 & $\begin{array}{l}18 . \\
1\end{array}$ & $\begin{array}{l}332 . \\
8\end{array}$ & $\begin{array}{l}\text { Speed of } \\
\text { agitation }\end{array}$ & 9 & 1 & 3 & 3 & 3 & 1 & 1 & 1 & 3 & 1 & 9 \\
\hline 8 & $\begin{array}{l}17 . \\
8\end{array}$ & $\begin{array}{l}328 . \\
6\end{array}$ & $\begin{array}{l}\text { Concrete } \\
\text { testing } \\
\text { frequency }\end{array}$ & 3 & 3 & 3 & 1 & 1 & 1 & 1 & 1 & 3 & 1 & 3 \\
\hline 9 & 7.5 & $\begin{array}{l}137 . \\
7\end{array}$ & $\begin{array}{l}\text { Labour and } \\
\text { helper } \\
\text { availability }\end{array}$ & 3 & 3 & 1 & 1 & 1 & 1 & 1 & 1 & 3 & 1 & 3 \\
\hline \multirow[t]{4}{*}{10} & 5.4 & $\begin{array}{l}100 . \\
0\end{array}$ & $\begin{array}{l}\text { Arrangements } \\
\text { of components }\end{array}$ & 3 & 3 & 3 & 1 & 1 & 1 & 9 & 1 & 3 & 1 & 3 \\
\hline & & & $\begin{array}{l}\text { Weightage/ } \\
\text { Importance }\end{array}$ & $\begin{array}{l}462 . \\
8\end{array}$ & $\begin{array}{l}287 . \\
8\end{array}$ & \begin{tabular}{|l}
285. \\
0 \\
\end{tabular} & $\begin{array}{l}366 . \\
0\end{array}$ & $\begin{array}{l}223 . \\
7\end{array}$ & $\begin{array}{l}143 . \\
4\end{array}$ & $\begin{array}{l}191 . \\
0\end{array}$ & $\begin{array}{l}290 . \\
5\end{array}$ & \begin{tabular}{|l}
300. \\
0 \\
\end{tabular} & $\begin{array}{l}190 . \\
6 \\
\end{array}$ & $\begin{array}{l}715 . \\
5 \\
\end{array}$ \\
\hline & & & $\begin{array}{l}\text { Relative } \\
\text { weightage }\end{array}$ & 13.4 & 8.3 & 8.2 & 10.6 & 6.5 & 4.2 & 5.5 & 8.4 & 8.7 & 5.5 & 20.7 \\
\hline & & & Rank & 2 & 6 & 7 & 3 & 8 & 10 & 9 & 5 & 4 & 9 & 1 \\
\hline
\end{tabular}


Vol. 4, Issue 2, February 2017

\section{CONCLUSIONS}

QFD can prove to be an effective tool for quality monitoring of RMC since it focuses primarily on customer satisfaction. The quality characteristic expected by the customer from an RMC plant can be translated into the VoC table which can be directly incorporated into the QFD process. QFD provides a flexible framework which can be customized, modified, extended and integrated with other quality control process. According to the survey results, it has been observed that during the "product planning phase" the first five significant parameters that need to be taken care of in order of priority are "plant and equipment availability in proper functional mode" (weightage 15.8\%); "resource management" (14.9\%); "control on quality of incoming materials" (12.7\%) and "laboratory set-up) (12.3\%). Similarly, for "process control phase the most important parameter appears to be the "target workability at plant and site"(20.7\%). The RMC plant authorities need to incorporate the VoC requirements into the above mentioned phases of the QFD process to obtain a product which would satisfy the customer to the greatest possible extent. Some limitations of this research include the ambiguities in the $\mathrm{VoC}$ and also conflicts between the customer requirements. The effectiveness of the proposed QFD process would improve through its integration with other SPC tools for quality monitoring of RMC like CUSUM technique with v-mask, RACUSUM and MVCUSUM.

\section{REFERENCES}

[1] Bouchereau, V. and Rowlands, H. (2000) 'Methods and Techniques to help quality function deployment (QFD)' Benchmarking: An International Journal, Vol.7 (1), pp.8-19.

[2] Cristiano, J. J., Liker, J. K. and White, C. C (2001) 'Key factors in the successful application of Quality Function Deployment (QFD)' IEEE Transactions on Engineering Management, Vol. 48(1), pp 81-95.

[3] Govers. C.P.M. (1996) 'What and how about quality function deployment' International Journal of Production Economics Vol. 46-47, pp 575-585.

[4] Heizer, J. and Render, B. (2006) Operations Management, 8th Edition, Pearson Edu Inc, New Jersey

[5] Jaiswal, E. S. (2012) 'A case study on Quality Function Deployment' Journal of Mechanical and Civil Engineering, Vol. $3(6)$, pp 27-36.

[6] Kamara, J. M., Anumba, C. J., and Evbuomwan, N. F. O. (1999) 'Client requirements processing in construction: A new approach using QFD.' J. Arch. Engrg. ASCE, Vol. 5(1), pp 8-15.

[7] Pheng, L. S. and Yeap, L (2001) 'Quality Function Deployment in Design/Build Projects' Journal of Architecture Engineering, ASCE, Vol. 7( 2), pp 30-39.

[8] Sarkar, D. and Bhattacharjee, B. (2003) 'Quality monitoring of ready mixed concrete using cusum system' Indian Concrete Journal, Vol. 77(2), pp 1060-1065.

[9] Sarkar, D. and Thaker, M (2007) 'Operating Characteristic Curves: Design and Application for Online Quality Monitoring of Ready Mixed Concrete' NICMAR Journal of Construction Management, Vol. XXII (III), pp $46-56$.

[10] Sarkar, D. and Dutta, G. (2010) 'Design and application of Risk adjusted cumulative sum for strength monitoring of Ready mix Concrete' Journal of Construction Engineering and Management ASCE, Vol. 136(6), pp 623-631.

[11] Sarkar, D. (2009) 'EWMA and CUSUM Control Charts for Online Strength Monitoring Of Ready Mixed Concrete' The Journal of Institution of Engineers (India), Vol. 90(1), pp 19-23.
[12] Sarkar, D. and Dutta, G. (2009) 'Economic Design of CUSUM Control Charts for Indian Ready Mixed Concrete Industry' NICMAR Journal of Construction Management, Vol. XXIV (III), pp 22-27. 